\title{
The methodology of a complex engineering-geological approach to establish a geopark: case study of the Małopolska Wisła River Gorge
}

\author{
Joanna PINIŃSKA ${ }^{1,{ }^{*}}$, Andrzej DOMONIK ${ }^{1}$, Artur DZIEDZIC ${ }^{1}$ and Dominik ŁUKASIAK ${ }^{1}$ \\ 1 University of Warsaw, Faculty of Geology, Żwirki i Wigury 93, 02-089 Warszawa, Poland
}



Pinińska, J., Domonik, A., Dziedzic, A., Łukasiak D., 2015. The methodology of a complex engineering-geological approach to establish a geopark: case study of the Małopolska Wisła River Gorge. Geological Quarterly, 59 (2): 408-418, doi: 10.7306/gq.1181

\begin{abstract}
Małopolska Wisła River Gorge is located in the middle stretch of the Wisła valley between Zawichost and Puławy. Its great portion is supposed to be turned into a geopark safely approachable by tourists along walking trails leading to planned geosites. While general criteria of geosite selection are oriented on promoting expected interesting attributes of the planned geopark or, in a special case, on recognizing possible strong geological hazards such as volcanic, earthquake and tsunami phenomena, the inner problems of tourist safety are not commonly recognized. The Wisła Gorge and its close vicinity of geopark is dedicated to cultural heritage, geological history, landscape and local folklore. The inner hazards of disasters are created here by steep, slippery paths, collapsible loessial canyons, rock-falls from weathered rock-walls, and high waters of the nearby river channel running alongside or flooding tourist footpaths. Recognition and preventing measures against such hazard require determination of the current engineering-geological conditions by testing rock and soil properties along the gorge, and by checking the likelihood of natural disturbance of the terrain safety. The vulnerability of exposed rocks to processes of natural erosion, steady weathering progress, turning steep clayey bluffs into slippery ground, and to an impact of long-term anthropogenic factors had to be recognized, checked, and tested for a final assessment of suitability of the selected place to serving as a geopark. The special prognostic procedure of engineering-geological hazards was recommended, applicable prior to the geopark planning stage. The procedure encompasses a thorough assessment of possible safe accessibility to particular geosites in the area designated to become a geopark. The suitability of the selected area to serving as a geopark was, thus, analysed methodically with regard to a detailed engineering-geological and geomechanical evaluation of possible hazard factors within the whole terrain. Proven engineering geological methodologies were employed for the hazard assessment procedure. Each of the factors was subjected individually to close examination, with results recorded into a GIS integrated informative layer, and envisioned upon digital thematic maps. These maps remain to be used for the preparation of regional suitability maps of specific engineering-geological conditions.
\end{abstract}

Key words: geopark, geosite, Małopolska Wisła Gorge, touristic and maintenance safety, GIS integrated digital engineering-geological maps.

\section{INTRODUCTION}

The gorge of the Wisła River in Małopolska is a unique cultural and environmental assemblage, whose geodiversity allows for establishing a geopark (Alexandrowicz and Miśkiewicz, 2007). The geodiversity comprises the regional and prehistoric settlement and mining heritage as well as fortified and sacral architectural objects built of local stones, richness of geomorphological landforms and geological sites of scientific significance. Besides, the valley of middle Wisła is a special area of a well-known historical water trade route from southern Europe to the Baltic Sea. It has made a significant impact on economic development of the region and a unique style of the Middle Age and Renaissance stone architecture. Availability of

* Corresponding author, e-mail: joanna.pininska@uw.edu.pl

Received: February 3, 2014; accepted May 8, 2014; first published online: July 22, 2014 common Upper Cretaceous and locally Paleogene and Neogene carbonate rocks from easily accessible, exposed slopes of the river, have been favourable to building industry prosperity. Following the development of the mining of siliceous limestone rocks (opoka), commonly known as a "white stone", urban complexes were formed with a characteristic architecture, exerting considerable impact on the cultural landscape of the region. The evidence of this influence is to this day preserved in a medieval character of the urban layout of Kazimierz Dolny and its stone architecture, changed in the 16th century from the wooden fire-prone to masonry one (Pinińska, 2007; Pinińska and Dziedzic, 2007; Harasimiuk et al., 2011).

The goals of the planned establishing of the Małopolska Wisła Gorge Geopark are very comprehensive (Harasimiuk et al., 2011). Generally, they are focused on the protection of the complex geoenvironmental assemblage of features comprising abiotic natural objects, endorsement of environmental education, inspiration of scientific research, and promotion of the geological tourism within the area; all with the expectation to enhancing economic development of local communities. Such attentive and educational activities in the geopark will be sup- 
ported by selecting and presenting various geological objects of abiotic nature (the geosites) having crucial, unique significance for the societal knowledge. The designed geosites represent abiotic objects interconnected by a walking trail network (Harasimiuk, 2007; Machalski et al., 2009; Harasimiuk et al., 2011; Warowna et al., 2013). Those objects will characterize a variety of morphological, geological, mining and cultural aspects in the region of the middle stretch of the Wisła River. Because of their regional importance, the planned Wisła River Gorge Geopark appears as a model for implementing safety measures based on comprehensive engineering-geological hazard studies. While general criteria of geosite selection (Dmytrowski and Kicińska, 2011) relate to expected interesting attributes of a planned geopark, the recognition of possible hazards will help in redesigning the previously planned tourist path network, and selection of new interesting sites of safer access (Pinińska, 2007; Coli et al., 2014; Pires et al., 2014).

For the purpose of recognizing possible obstacles in the planning and establishing of the whole geopark area with numerous geosites, an engineering-geological methodology of classification and categorization of terrain landform, rock and soil units was developed. The classification comprises three categories of terrain properties within soily and rocky landscapes, vulnerable to geodynamic hazardous processes, allowing zone selection where new geosites are considered. Results recorded into the GIS, are integrated and envisioned upon digital thematic engineering-geological maps.

\section{GEOLOGICAL-ENGINEERING RECOGNITION OF ROCK AND SOIL UNITS}

Geosites selected for tourists are distributed within the geopark in areas of miscellaneous properties of Quaternary soils and Cretaceous, Paleogene and Neogene rocks, and of variable morphology (Harasimiuk and Henkiel, 1978). Many geosites are planned in a direct contact with the oscillating water table in the Wisła River channel. Thus, the safety conditions within their locations and the safe accessibility were analysed on the basis of available complex engineering-geological data.

The categorising of soils and rocks within the projected geopark was related to these geodynamic processes which were potentially hazardous to park visitors, such as landslides, rock-falls, stone drops and slides, erosion, wash-outs, debris creep, debris and mud flows, sink-holing and collapses. In making the vulnerability parameters credible, each of the distinguished categories was cross-verified by results of field and laboratory studies, in agreement with European classification standards of soils and rocks.

For the Wisła River Gorge, a particular attention is focused on hazardous rock masses forming high and steep rock slopes. Other subjects of a close study were localities of historical mining activity. These areas were subjected to increasing hazard posed by artificially exposed steep walls of former opencast mining activity, now becoming rock-fall prone. According to complex studies focused on the qualitative evaluation of rock exposures within the proposed geosites, the selection of technical parameters was decisive for selecting potentially safe areas and their inter-connecting footpaths for use as touristic entities.

The cataloguing of rock geosites, as well as evaluation of the state of walls in natural exposures and in former mining surface quarrying and underground excavations indicate that they are at a variable degree of destruction, thus differently vulnera- ble to further development of surface weathering processes. The present stability state and the vulnerability to a long-term erosion, the transformation of walls in selectable geosites were evaluated by a series of field and laboratory technical investigation data. Results of studies were used for preparing special requirements of the Geomechanical Assessment Chart for each planned rock geosite (Fig. 1), dedicated to the geopark. The chart contains the complex geomechanical characteristics of in situ rock massif conditions and deformation features, and data on the durability of particular rock to deterioration, determined in the laboratory. All such charts store more than 50 various technical parameters.

Field, in situ engineering studies include exploring of the weathering profile within the rock massif (Dragowski, 1965), assessing discontinuities, type of fracturing, dampness and water manifestations. The state of rock mass was determined on the basis of 10 separate factors (according to PN-EN-ISO-14689-1, 2006), three factors of fissurity (according to PN B-02408) and the index of rock quality designation (RQD). Final assessments were performed according to recommendable classifications by Bieniawski (1974) and Geological Strength Index (Hoek and Brown, 1997).

The laboratory studies, conducted on prepared monolith samples of rocks collected from exposures at particular geosites, included microstructural characteristics, analysis of physical and mechanical features of rock material and their weathering resistance. Samples from the monolith zone were mainly collected in exposures at geosites from steep rock walls, which are supposedly hazardous to visitors and maintenance. From each tested geosite, 30 rock samples were collected and 15 different groups of parameters were determined. In seeking deterioration factors on a long-term scale and its dynamics caused by natural weathering and anthropogenic influence, the following events were subjected to experimental modelling: impacts of surface salting, acid rains and air pollution. Some of these studies were closely related to European standards, e.g. in determining the resistance to salt crystallisation (PN-EN 12370,2001 ) or establishing the resistance to $\mathrm{SO}_{2}$ impact under humid conditions (PN-EN 13919, 2004); others required individually determined procedures, not comprised in standards (Pinińska and Dziedzic, 2006; Pinińska, 2007; Kłopotowska and Łukasiak, 2011; Bukowska, 2013; Kłopotowska and Łukaszewski, 2013; Łukasiak, 2013). The non-destructive ultrasonic research methods with registering changes of longitudinal wave velocity $\left(V_{p}\right)$, have been applied in monitoring structural defects and changes of rock durability caused by deterioration processes under laboratory conditions. The results of experimental data were used in evaluation of long-term structural weakening of rocks, and the final losing of stability of the rock massif.

Recognition of soil unit properties within the geopark area, which have been earlier studied in detail, are based on available archived data and publications (Drągowski, 1965; Kaczyński, 1965; Łodzińska, 1965; Stochlak, 1965; Myślińska, 2004; Pinińska and Dziedzic, 2006, 2007). Recognition of loess and derivative soils with their variable properties has been sufficiently detailed and precisely documented in earlier reports (Harasimiuk and Henkiel, 1978; Gardziel et al., 1996; Frankowski and Grabowski, 2006). Particularly useful for the categorization of non-rocky ground mass within the proposed geopark were places of specific engineering-geological conditions recognized for the former, not implemented, Wisła River cascade project near Kazimierz Dolny (Łodzińska, 1965). 


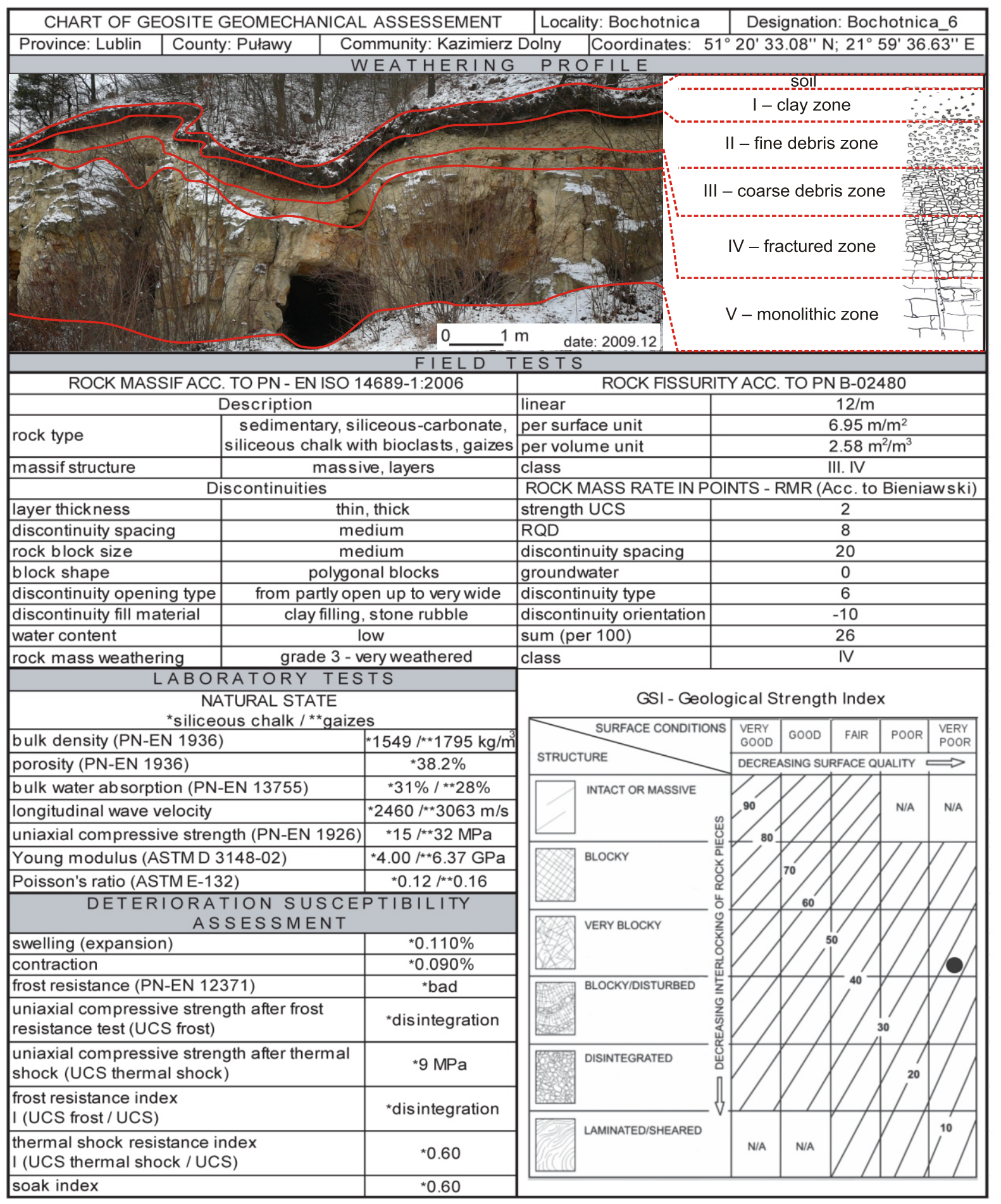

Fig. 1. Chart of the Geosite Geomechanical Assessment, which provides an engineering-geological complex documenting of a single geosite; this chart (Bochotnica_6 geosite) contains information on the Medieval Bochotnica siliceous chalk mine

Black dot represents resulting GSI index - the properties of rocks surrounding the mine entrance correspond to engineering category II in Table 1 


\section{GEOLOGICAL-ENGINEERING CATEGORIZATION OF ROCK AND SOIL UNITS}

All geological units of the area designated for geopark were categorized into three general engineering-geological categories due to complex analysis, separately for the rock massif ( $\mathrm{Ta}$ ble 1) and soils (Table 2), according to their properties, prospectively hazardous for visitors, and causing the need of mark maintenance:

- category I - least vulnerable,

- category II - medium vulnerable,

- category III - most vulnerable.

The applied criteria of the above categorization of the rock massif at the geosite included: laboratory determined strength parameters of rocks, their susceptibility to deterioration according to PN-EN ISO 14689-1 (2006), Rock Mass Rating (RMR) index according to Bieniawski (1974), and Geological Strength Index by Hoek and Brown (1997) with average values as follows: category I - RMR mostly III, GSI > 50, susceptibility for deterioration 2; category II - RMR mostly IV, GSI < 50, susceptibility for deterioration 3; category III - RMR V, GSI < 20, susceptibility for deterioration 3 .

All the three categories of rock massif significantly refer to the stratigraphic position (age) and lithology of the classified rock units within the Wisła River Gorge Geopark (Table 1).

The applied criteria of categorization of soil units (Table 2) included: vulnerability to changes of texture (in cohesive soils), density level (in loose soils), macroporosity (in macroporous soils), and surface mobility of loose material (debris flows, slope wash). The risk of losing the stability of soft rock slopes and the prospective hazard of geodynamic phenomena in soils were, in most of places, different than in the rocky slopes. The loess areas of characteristic, distinct morphology with numerous gorges, ravines and steep walls were particularly vulnerable to impact of rain- and meltwaters, which usually initiate miscellaneous collapsing and landslide processes (Borecka and Kaczmarczyk, 2007).

Based on these data, the soil units have been classified into three hazard categories of non-rocky massifs, characterizing various degrees of hazard related to surface geodynamic processes.
Those three categories are also significantly related to the stratigraphic position (age) and lithology of the soil units.

The data, characterizing all the geological units and rock and soil (non-rocky) massifs in the projected geopark area with regard to their engineering-geological properties, and categorized according to their vulnerability to changes under the impact of external geodynamic processes, were incorporated into the geographic information system (GIS). The importance of tying specific geosite engineering-geological properties and massif hazard categorization with the GIS, allows spatial control also of available geomechanical data in various aspects and their input to the geological-engineering thematic maps and applicable for any area to be studied for the further society-environment-tourism interaction.

\section{GEOLOGICAL-ENGINEERING ZONE SELECTION MAPS}

The already collected data and their placement in the classification table helps developing an essential tool in a comparative analysis of rock and soil massif stability in different regions and selected the unified terrain safety level in the geopark area. Terrain selection of areas with engineering-geological conditions favourable for locating of particular geosites, and delineating courses of the interconnecting walking trails can be made consisted with standard planning and safety requirements.

Three specific engineering-geological factors within the planned geopark determine the conditions and durability of the geosites and geotouristic trails. These are:

1. engineering-geological properties of rock and soil (non-rocky) units, related to the massif categories I, II and III;

2. slope angles;

3. oscillating water level of the Wisła River.

These factors were the basis for the preparation of the three separate GIS layers, with data visualized in digital thematic maps of engineering-geological zoning of the geopark terrain:

1. Map of Engineering-Geological Properties of massifs (Fig. 2), comprising the categorization of rock-units within areas

Engineering-geological categorization of rock massifs

\begin{tabular}{|c|c|c|c|}
\hline \multicolumn{4}{|c|}{ CATEGORIZATION OF ROCK MASSIFS } \\
\hline CATEGORY & Lithology & Age & Exposure/geosite \\
\hline \multirow{3}{*}{ I } & limestones & Cretaceous & Janików \\
\hline & siliceous chalk & Cretaceous & Kazimierz Dolny \\
\hline & siliceous chalk & Cretaceous & Opoczka Mała \\
\hline \multirow{6}{*}{ II } & siliceous chalk & Cretaceous & Piotrawin \\
\hline & $\begin{array}{c}\text { siliceous chalk, } \\
\text { limestones and gaizes }\end{array}$ & Cretaceous/Paleogene & Bochotnica \\
\hline & siliceous chalk & Cretaceous & Dziurków \\
\hline & $\begin{array}{l}\text { siliceous chalk, } \\
\text { sandstones }\end{array}$ & Cretaceous/Paleogene & Nasiłów \\
\hline & marly siliceous chalk & Cretaceous & Podgórz \\
\hline & siliceous chalk & Cretaceous & Sulejów \\
\hline \multirow{3}{*}{ III } & siliceous chalk & Cretaceous & Ciszyca Górna \\
\hline & limestones, sandstones & Neogene & Kamienna Góra \\
\hline & siliceous chalk & Cretaceous & Nowe \\
\hline
\end{tabular}


Engineering-geological categorization of soil massifs

\begin{tabular}{|c|c|c|}
\hline \multicolumn{3}{|c|}{ CATEGORIZATION OF NON-ROCKY MASSIFS } \\
\hline CATEGORY & Lithology & Age \\
\hline \multirow{2}{*}{ I } & $\begin{array}{c}\text { clay deposits (glacial) and sands, gravels, } \\
\text { erratic boulders }\end{array}$ & \multirow{2}{*}{ Quaternary } \\
\hline & $\begin{array}{c}\text { clay deposits and erratic boulders, gravels and } \\
\text { residuum sands }\end{array}$ & \\
\hline \multirow{9}{*}{ II } & aeolian sands (dunes) & \multirow{2}{*}{ Quaternary } \\
\hline & aeolian sands & \\
\hline & \begin{tabular}{|c|} 
loesses with paleosols, muds, sandstones and \\
loess-like silts
\end{tabular} & $\begin{array}{c}\text { Quaternary-Vistulian } \\
\text { Glaciation }\end{array}$ \\
\hline & glaciofluvial sands an gravels & \multirow{5}{*}{$\begin{array}{l}\text { Quaternary-Odranian } \\
\text { Glaciation }\end{array}$} \\
\hline & $\begin{array}{l}\text { ice-dammed lake clays, muds, and sands } \\
\text { (not separated) }\end{array}$ & \\
\hline & sands and muds of kame and kame-terraces & \\
\hline & $\begin{array}{c}\text { gravels, boulders and sands of bank moraines } \\
\text { and dead-ice blocks } \\
\end{array}$ & \\
\hline & $\begin{array}{c}\text { sands and gravels of eskers and glacial } \\
\text { crevasse landforms }\end{array}$ & \\
\hline & river sands and gravels, partly glaciofluvial & $\begin{array}{l}\text { Quaternary - South } \\
\text { Polish Glaciations }\end{array}$ \\
\hline \multirow{7}{*}{ III } & peats and peaty muds & \multirow{5}{*}{ Quaternary } \\
\hline & gyttjas, lake chalks and muds of old river beds & \\
\hline & $\begin{array}{c}\text { sand and muds of ground valleys, landlocked } \\
\text { depressions and alluvial fans }\end{array}$ & \\
\hline & sands, silts and clay deposits of slope washes & \\
\hline & $\begin{array}{l}\text { residual-weathering gravels, sands, muds and } \\
\text { boulders }\end{array}$ & \\
\hline & $\begin{array}{l}\text { sands, gravels and rivers muds of overflood } \\
\text { terraces }\end{array}$ & $\begin{array}{l}\text { Quaternary-Vistulian } \\
\text { Glaciation }\end{array}$ \\
\hline & sands, gravels and rivers muds & $\begin{array}{c}\text { Quaternary-Mazovian } \\
\text { Interglacial }\end{array}$ \\
\hline
\end{tabular}

of specific engineering-geological properties of soils and rocks to the three vulnerability categories (I, II and III).

2. Slope Angle Map, showing three types of areas with variable potential for the presence and development of geodynamic processes (Fig. 3):

- flat areas with a slope angle $<5^{\circ}$, of least hazard;

- areas with slope angle between $5-20^{\circ}$, of low hazard;

- areas with slope $>20^{\circ}$, of potentially high hazard caused by geodynamic phenomena.

3. Map of Areas Endangered by Flooding (Fig. 4). Areas endangered by flooding from the Wisła River and significant increase of groundwater level have been analysed for the high-water events in the Wisła River in the interval prior to the preparation of the geopark project. The historical groundwater level at $121 \mathrm{~m}$ a.s.l. in Puławy and $143 \mathrm{~m}$ a.s.l. in Zawichost was analysed in relation to the current water-level gauge readings, as well as the discussions of Kaczyński (1965) and Łodzińska (1965) referring to the planned river water lifting.

These three thematic maps were used to produce a compiled Regional Map of Specific Geological-Engineering Hazardous Conditions for the Wisła River Gorge Geopark according to the criteria presented in Table 3 . The basic criterion was the safety of visitors on the path grid within the geosite area, endan- gered by hazard of slippery, rock falls and flooding. The following areas have been distinguished:

- least hazardous areas;

- medium hazardous areas;

- hazardous areas;

- areas endangered by flooding.

Regional Map of Specific Geological-Engineering Hazardous Conditions (Fig. 5) shows areas that are variably vulnerable to the development of geodynamic conditions, thus influencing the criteria of constructing, making available, and long-term managing of geosites and walking trails. These sub-divisions are strictly regional and relative. They reflect the engineering-geological variability of local hazard conditions in the Małopolska Wisła Gorge Geopark.

Analysis of the areas with specific engineering-geological conditions indicates that areas vulnerable to the development of geodynamic processes occur mainly at the marginal zones of the Wisła River valley and in areas with loess canyons. Most geosites and geotrails are located in areas of medium and least vulnerability to geodynamic hazards.

In turn, high hazard in correct functioning of geotouristic trails is linked with the oscillating water level in the Wisła River. It refers to geosites and geotouristic trails located within the flood terrace of the Wisła River and in the vicinity of Wilków, wherethe 


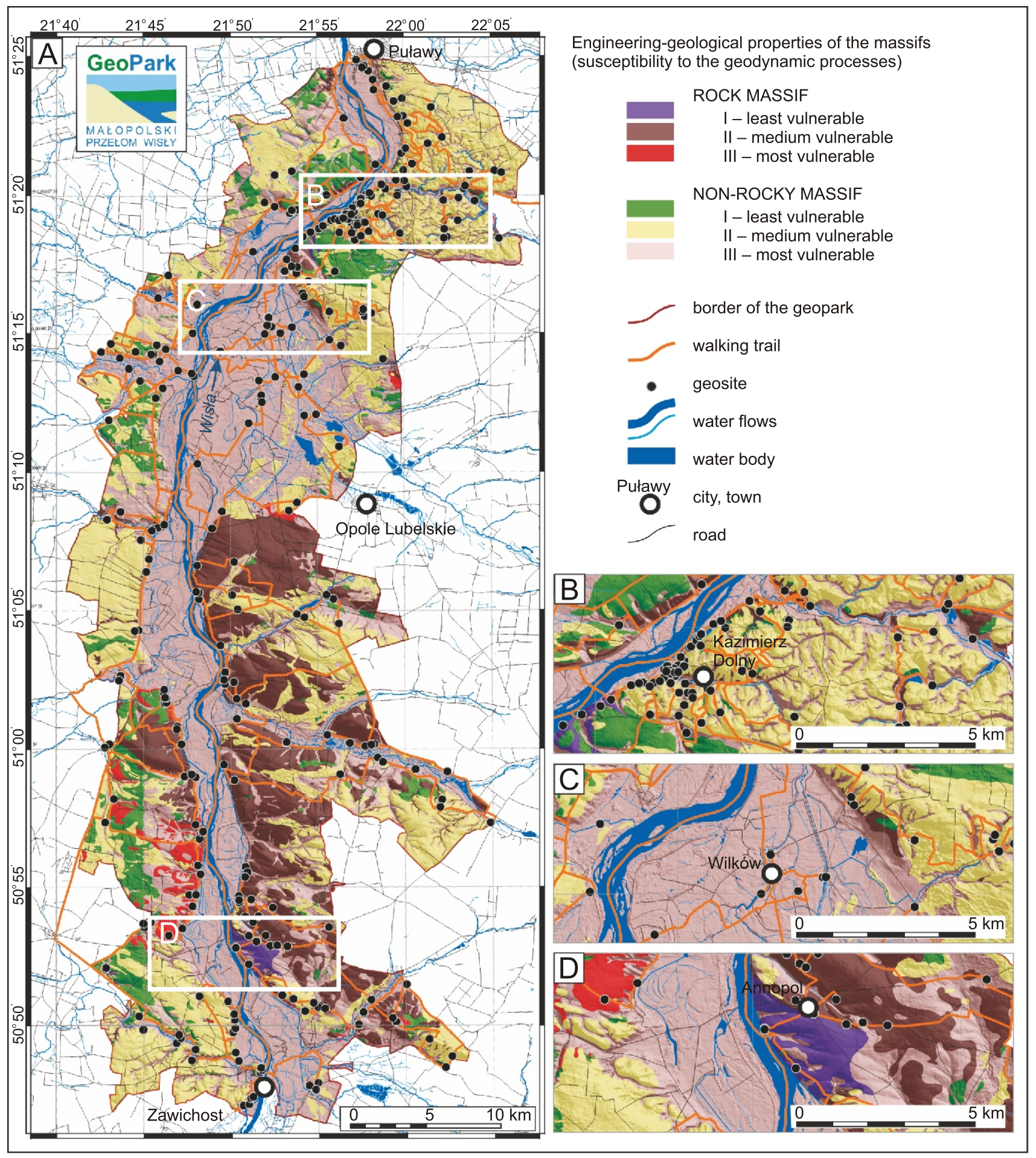

Fig. 2. Map of Engineering-Geological Properties of rocky and non-rocky massif units in the area of planned Małopolska Wisła Gorge Geopark 


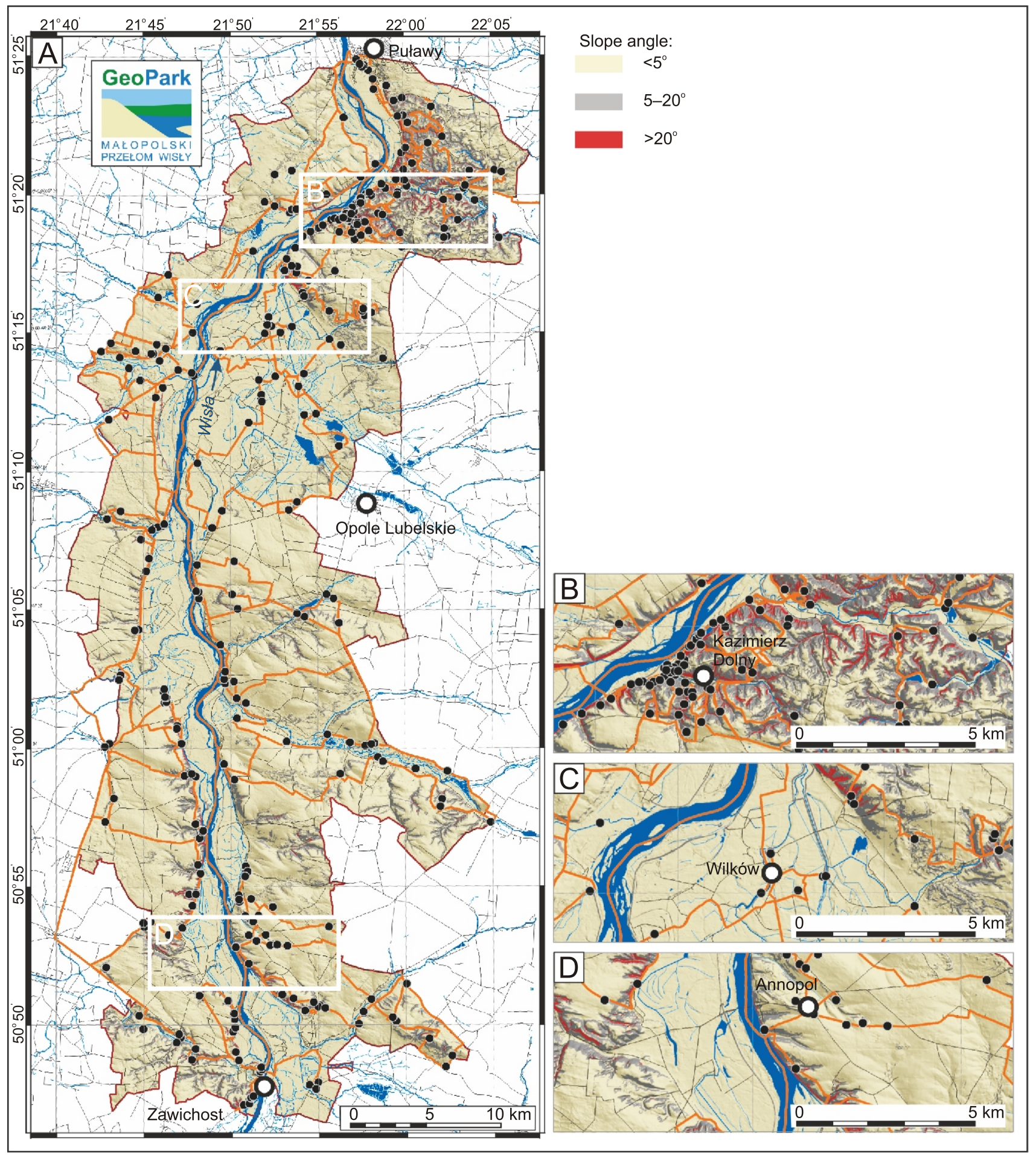

Fig. 3. Slope Angle Map in the area of planned Małopolska Wisła Gorge Geopark

Other explanations as in Figure 2 


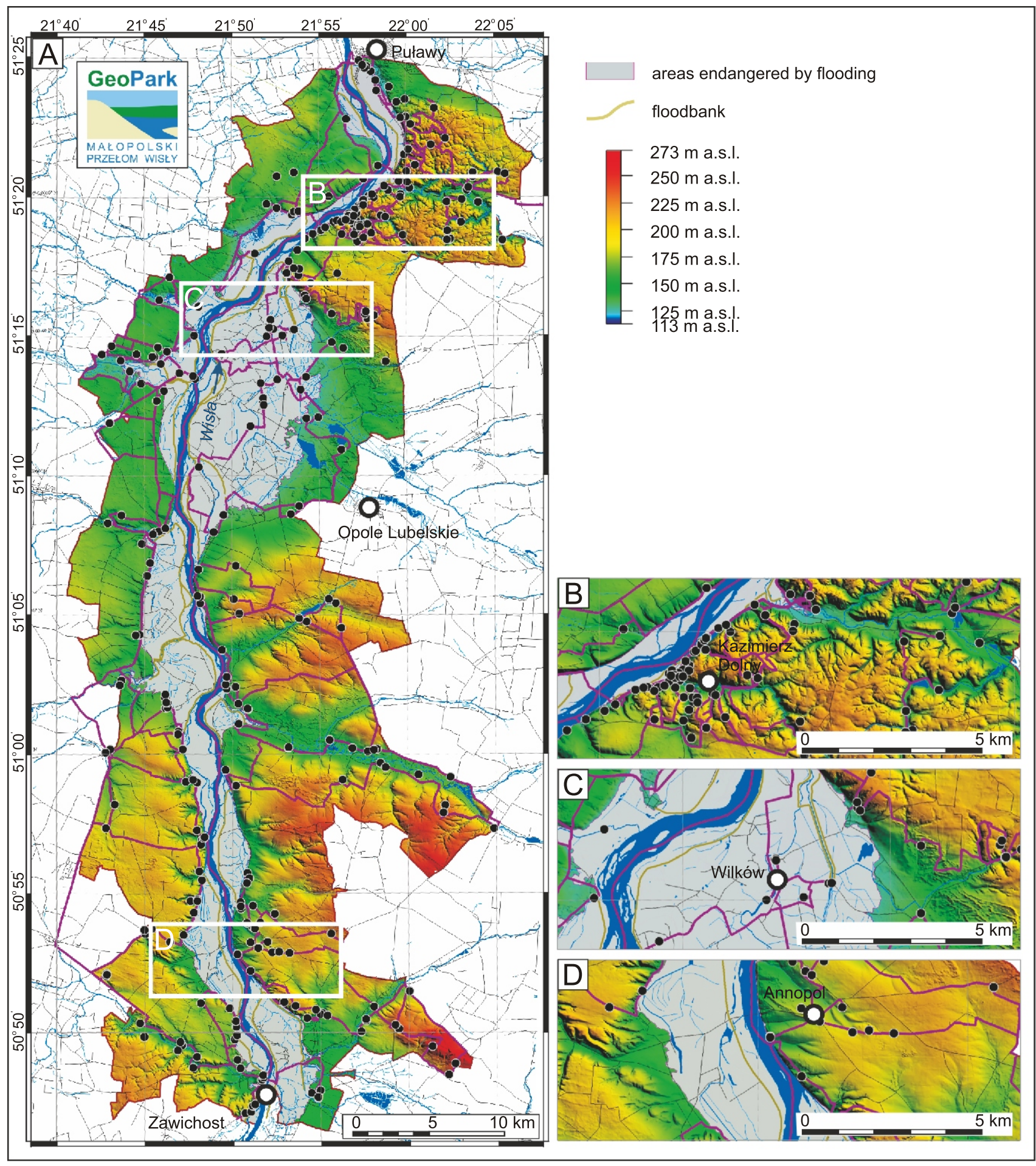

Fig. 4. Map of Areas Endangered by Flooding in the area of planned Małopolska Wisła Gorge Geopark

Other explanations as in Figure 2 


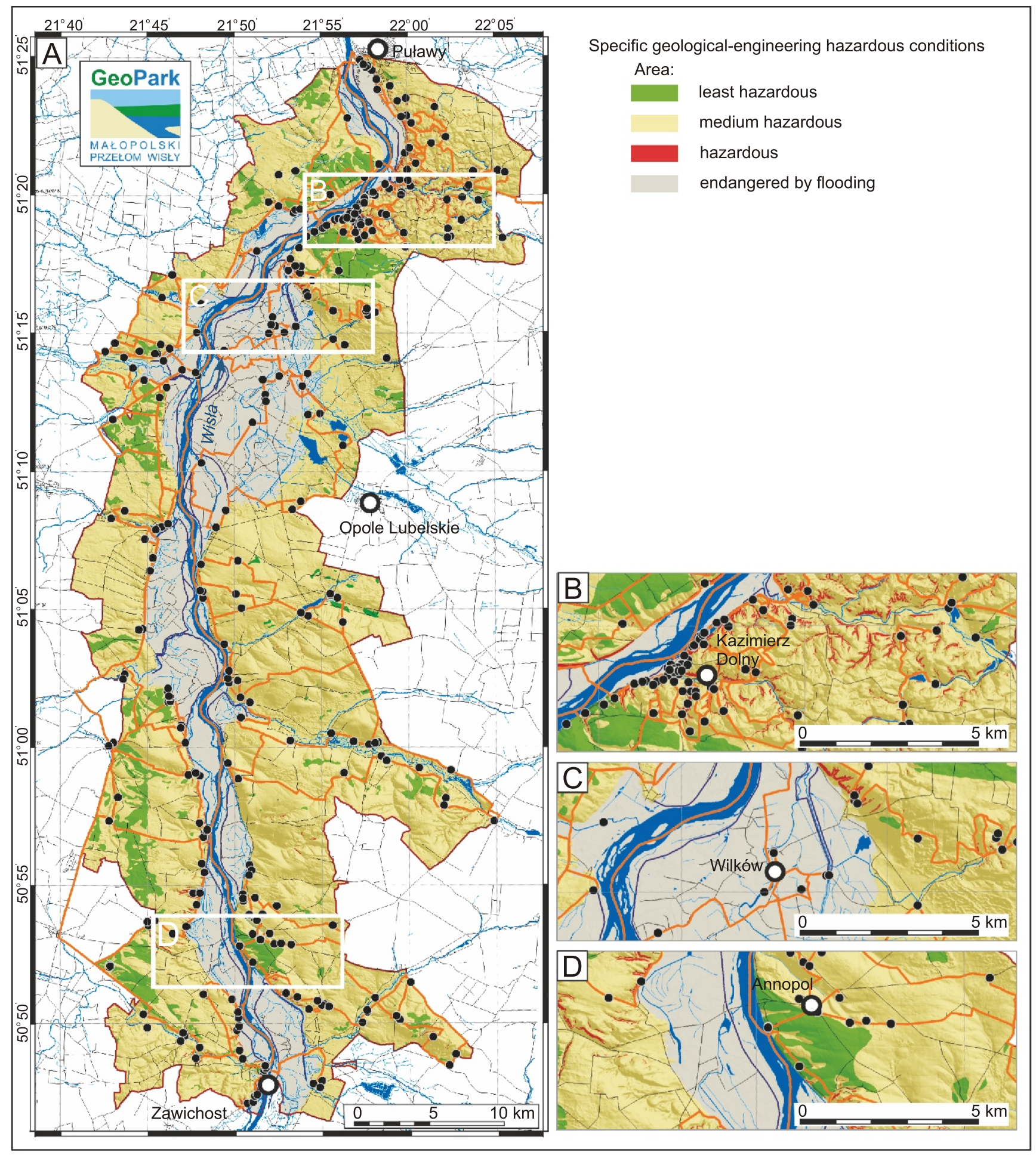

Fig. 5. Regional Map of Specific Geological-Engineering Hazardous Conditions in the area of planned Małopolska Vistula Gorge Geopark

Other explanations as in Figure 2 
Ta ble 3

Criteria used in distinguishing areas with specific geological-engineering hazards

\begin{tabular}{|c|c|c|c|c|c|}
\hline & & \multicolumn{3}{|c|}{ Categorization of soils and rocks } & \multirow{2}{*}{ Flooding } \\
\hline & & 1 & II & III & \\
\hline \multirow{3}{*}{ 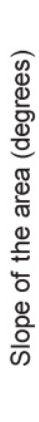 } & $<5$ & $\begin{array}{c}\text { Least } \\
\text { hazardous } \\
\text { areas }\end{array}$ & $\begin{array}{c}\text { Medium } \\
\text { hazardous } \\
\text { areas }\end{array}$ & $\begin{array}{c}\text { Medium } \\
\text { hazardous } \\
\text { areas }\end{array}$ & \multirow{3}{*}{$\begin{array}{l}\text { Areas } \\
\text { endangered } \\
\text { by flooding }\end{array}$} \\
\hline & $5-20$ & $\begin{array}{c}\text { Medium } \\
\text { hazardous } \\
\text { areas }\end{array}$ & $\begin{array}{l}\text { Medium } \\
\text { hazardous } \\
\text { areas }\end{array}$ & $\begin{array}{c}\text { Medium } \\
\text { hazardous } \\
\text { areas }\end{array}$ & \\
\hline & $>20$ & $\begin{array}{c}\text { Medium } \\
\text { hazardous } \\
\text { areas }\end{array}$ & $\begin{array}{c}\text { Hazardous } \\
\text { areas }\end{array}$ & $\begin{array}{c}\text { Hazardous } \\
\text { areas }\end{array}$ & \\
\hline & $\begin{array}{l}\text { 음 } \\
\frac{\mathrm{O}}{4} \\
\frac{\mathrm{O}}{4}\end{array}$ & \multicolumn{3}{|c|}{$\begin{array}{c}\text { Areas } \\
\text { endangered } \\
\text { by flooding }\end{array}$} & \\
\hline
\end{tabular}

rise of flood waters in 2010 caused severe damage to households and infrastructure.

These maps containing forecast data on technical availability and maintenance conditions for trails and geosites may serve for their planned selection with implemented hints on a proper tourist security and economy measures.

\section{SUMMARY}

The project area of the planned Małopolska Wisła Gorge was considered for its specific geological-morphological location. A characteristic of the project plan was the geopark location inside the Wisła River valley and in its vicinity, with numerous gorges, ravines and steep canyons with walls of macroporous loess soils, floodplains and alluvial terraces as well as steeply inclined cliffs built of relatively soft calcareous rocks. Such diverse morphology in connection with variable soil and rock properties, and the hazards of seasonal flooding phenomena, imposed the application of a complex investigative engineering-geological methodology dedicated to special needs of geopark management. Regional categorization of exposed soil and rock units were prepared based on comprehensive field and laboratory studies. It was crucial especially in the case of steep rocky slopes with particularly interesting and educationally important geosites. Another evaluating approach to categorization was necessary for the geosites dispersed upon the Wisła River floodplains. Therefore, in the assessment of the geopark area, particular attention was drawn to evaluation of the geomechanical behaviour of rocks and soils on-site, under the changeable external conditions within the whole planned geopark area. Thus, slippery paths, exposed rocks in steep slopes, collapsible grounds as well as possibly unavailable access to sites prone to flooding became standard methodology research entries in the new geopark studies.

At the regional scale, the rocks in the area of the planned geopark are poorly resistant and form strongly fractured rock-units in a comparison to other stronger rock types elsewhere in Poland (compare the Geomechanical Data Base, Department of Geomechanics, University of Warsaw, 2010). Despite its weakening and fragility, the rocks exposed in the Małopolska Wisła Gorge have been used in building constructions since historical times. For this reason, some of old historical quarries need more protective measures, focused mainly on their availability for geotouristic activity, which in turn should be subjected to detailed engineering-geological studies.

The application of methodological approach to vulnerability assessment of the planned Małopolska Wisła Gorge Geopark has resulted in distinguishing three regions with various hazard level of vulnerability to dangerous geodynamic phenomena. The highest density of hazardous places occurs in the northern part of the designated geopark area and comprises geosites located in the marginal zones of the Wisła valley and in the steep embankments of loess canyons. Strong fragmentation of the rock mass and advanced erosion processes induce hazards of rock-fall, landslides, walls collapse and washing out of the loess slopes. An area of increased flood hazard was distinguished In the middle part of the planned geopark, where, however, a small number of geosites are planned. The southern part of the area designated to geopark is dominated by sites with medium and least vulnerability to disaster hazards, with the endangered geosites located only at the marginal zone of the Wisła River valley.

The presented case of assessment of the engineering-geological conditions within the Wisła River Gorge indicates that most of the designated geosites within the planned geopark are located in areas of medium vulnerability to the development of geodynamic processes. This factor is favourable for the accomplishment of the planned geopark goals, focused mainly on the common availability of natural monuments and on the educational character of the proposed walking trail network, as reflected in summarising maps.

The application of multi-range analysis of engineering-geological conditions was essential in characterizing the local details of changes of soil and rock properties and the geological, morphological and hydrographical conditions in the study area. It is obvious that such studies must be completed after the geosites are proposed but prior to final establishing of the geopark extent with its swarm of geosites and a network of interconnecting trails. Services made available by GIS are significant and allow the satisfactory achievement of targets - a selection of interesting geosites, safe for touristic activity. The invented methodology procedure, based on field and laboratory researches, appear useful in selecting and assessing of areas favourable for establishing the geopark and associated geosites. The application of GIS allows easy visualization of results in an understandable and comparable set of thematic maps. In this way, the detailed geoenvironmental properties of the study area can be made obviously available for the decision-makers and the concerned society.

Acknowledgements. The authors are very grateful to Prof. J. Delgado and S. Rybicki for their careful review of the manuscript and very fruitful suggestions. We also appreciate of several years company of the Prof. M. Harasimiuk and his team during the joint work at the Wisła River Gorge Geopark, supported by the NFOŚiGW. 


\section{REFERENCES}

Alexandrowicz, Z., Miśkiewicz, K., 2007. Światowa sieć Narodowych Geoparków UNESCO (procedura tworzenia) (in Polish). Chrońmy Przyrodę Ojczystą, 63: 3-14.

Bieniawski, Z.T., 1974. Geomechanics classification of rock masses and its application in tunneling. Proceedings of the Third International Congress on Rock Mechanics. International Society for Rock Mechanics, Denver.

Borecka, A., Kaczmarczyk, R., 2007. Engineering geology evaluation of landslide hazard of south-eastern Polish loess formations (in Polish with English summary). Geologos, 11: 347-356.

Bukowska, M., 2013. Post-peak failure modulus in problems of mining geo-mechanics. Journal of Mining Science, 49: 731-740.

Coli, M., Livi, E., Erbetta, I., 2014. Hazard analysis for rock-fall onto touristic beaches from overhanging cliffs in ophiolitic rock-mass. EUROCK, Rock Engineering and Rock Mechanics: Structures in and on Rock Masses. Vigo. Proc., 276.

Drągowski, A., 1965. Inżyniersko-geologiczna charakterystyka zwietrzelin utworów dolno mastrychckich przełomowego odcinka Wisły środkowej i przyległych wyżyn (in Polish). Mat. Symp. w Kazimierzu Dolnym: "Geologiczne problemy zagospodarowania Wisły Środkowej od Sandomierza do Puław": 151-161. Stowarzyszenie Inżynierów i Techników Górnictwa.

Dymtrowski, P., Kicińska, A., 2011. Geotourism valuation of unbiotic objects and their signification in prospect of geopark development (in Polish with English summary). Problemy Ekologii Krajobrazu, 29: 11-20.

Frankowski, Z., Grabowski, D., 2006. Engineering-geological and geomorphological conditions of gully erosion in loess deposits in the Kazimierz Dolny area (Opolska Droga Gully) (in Polish with English summary). Przegląd Geologiczny, 54: 777-783.

Gardziel, Z., Harasimiuk, M., Rodzik, J., 1996. Dynamika procesów geomorfologicznych w zlewni Grodarza i związane z nimi zagrożenia dla Kazimierza Dolnego (in Polish). In: Małopolski przełom Wisły - walory, zagrożenia, ochrona (ed. M. Kucharczyk): 21-31. Wydawnictwo Uniwersytet Marii Curie-Skłodowskiej, Lublin.

Harasimiuk, M., 2007. Stanowiska geomorfologiczne regionu lubelskiego jako narzędzie rozwoju geoturystyki (in Polish). In: Budowa geologiczna regionu lubelskiego i problemy ochrony litosfery (eds. M. Harasimiuk, T. Brzezińska-Wójcik, R. Dobrowolski, P. Mroczek and J. Warowna): 271-277. Wydawnictwo Uniwersytet Marii Curie-Skłodowskiej, Lublin.

Harasimiuk, M., Henkiel, A., 1978. Wpływ budowy geologicznej i rzeźby podłoża na ukształtowanie pokrywy lessowej w zachodniej części Płaskowyżu Nałęczowskiego (in Polish). Annales UMCS, sec. B, 30/31: 55-80.

Harasimiuk, M., Domonik, A., Machalski, M., Pinińska, J., Warowna, J., Szymkowiak, A., 2011. Małopolska Gap of Vistula River - projected geopark (in Polish with English summary). Przegląd Geologiczny, 59: 405-416.

Hoek, E., Brown, E.T., 1997. Practical estimates or rock mass strength. International Journal of Rock Mechanics and Mining Science \& Geomechanics Abstracts, 34: 1165-1186.

Kaczyński, R., 1965. Wpływ zmian reżimu hydrologicznego na warunki kopalni fosforytów „Annopol” (in Polish). Mat. Symp. w Kazimierzu Dolnym: „Hydrologiczne i inżyniersko-geologiczne problemy zagospodarowania Wisły Środkowej od Sandomierza do Puław": 148-158. Stowarzyszenie Inżynierów i Techników Górnictwa.
Kłopotowska, A., Łukasiak, D., 2011. Changeability of resistance of sandstone under conditions of crystallization of sodium sulfate and under influence of sulfur dioxide (in Polish with English summary). Biuletyn Państwowego Instytutu Geologicznego, 446: $143-148$

Kłopotowska, A., Łukaszewski, P., 2013. Susceptibility of rock materials used in the construction of monuments to long-term salt crystallization. In: Rock Mechanics of Resources, Energy and Environment, Eurock 2012: 293-297. The 2013 International Society for Rock Mechanics International Symposium, Wrocław, Poland.

Łodzińska, W., 1965. Mapa Geologiczno-Inżynierska, arkusz Kazimierz w skali 1:50 000 przykładem kartograficznego opracowania doliny Wisły Środkowej (in Polish). Mat. Symp. w Kazimierzu Dolnym: „Hydrologiczne i inżyniersko-geologiczne problemy zagospodarowania Wisły Środkowej od Sandomierza do Puław": 92-98. Stowarzyszenie Inżynierów i Techników Górnictwa.

Łukasiak, D., 2013. The influence of the selected deterioration processes on durability of the Godula sandstones from Brenna (in Polish with English summary). Górnictwo Odkrywkowe, 1: 56-61.

Machalski, M., Komorowski, A., Harasimiuk M., 2009. New chances in quest for Cretaceous marine vertebrates in abandoned phosphate mine at Annopol on Vistula River (in Polish with English summary). Przegląd Geologiczny, 57: 638-641.

Myślińska, E., 2004. Occurrence of aggregates in cohesive soils and their influence on evaluation of selected properties (in Polish with English summary). Przegląd Geologiczny, 52: 653-656.

Pinińska, J., 2007. Rock mining industry - the geological contribution to cultural heritage of Lublin region (in Polish with English summary). Biuletyn Państwowego Instytutu Geologicznego, 422: 97-111.

Pinińska, J., Dziedzic, A., 2006. Właściwości wytrzymałościowe i odkształceniowe skał (in Polish). Część V Region Lubelski, Katalog. Wydział Geologii UW.

Pinińska, J., Dziedzic, A., 2007. Właściwości wytrzymałościowe i odkształceniowe skał (in Polish). Część V Region Lubelski. Objaśnienia i interpretacja. Wydział Geologii UW.

Pires, H.I., Chamine, A., Perez-Alberti, A., Gomez, A., Rocha, F., 2014. Rock strength assessment and structural features analysis on rocky coasts. EUROCK, Rock Engineering and Rock Mechanics: Structures in and on Rock Masses. Vigo. Proc., 296.

Stochlak, J., 1965. Charakterystyka własności fizyczno-mechanicznych sypkich utworów czwartorzędowych przełomowego odcinka Doliny Wisły środkowej i wyżyn przyległych (in Polish). Mat. Symp. w Kazimierzu Dolnym: „Geologiczne problemy zagospodarowania Wisły Środkowej od Sandomierza do Puław": 97-124. Stowarzyszenie Inżynierów i Techników Górnictwa.

Warowna, J., Migoń, P., Kołodyńska-Gawrysiak, R., Kiebała, A., Zgłobicki W., 2013. Geomorphosites of Poland - the role played by the Central Register of Geosites. Landform Analysis, 22: 117-124.

Standards:

ASTM D 3148-02 (2005); ASTM E-132 (2010); PN-EN ISO 14689-1 (2006); PN-EN 12370 (2001), PN-EN 1926 (2001), PN-EN 13755 (2002), PN-EN 13919 (2004), PN-EN 1936 (2010), PN-EN 12371 (2010); PN B-02480 